Tomaszewska Katarzyna, Majchrowicz Bożena, Szewczyk Magdalena. Subjctive assessment of the quality of life of patients with rheumatological diseases. Journal of Education, Health and Sport. 2021;11(7):44-53. eISSN 2391-8306. DOI http://dx.doi.org/10.12775/JEHS.2021.11.07.004

https://apcz.umk.pl/czasopisma/index.php/JEHS/article/view/JEHS.2021.11.07.004

https://zenodo.org/record/5076448

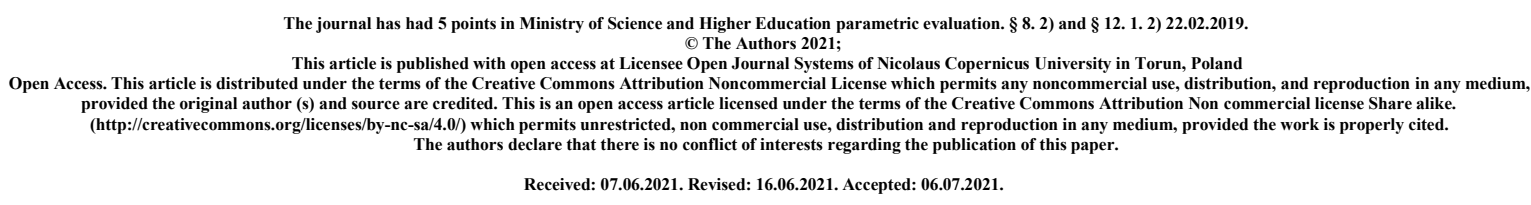

\title{
Subjetive assessment of the quality of life of patients with rheumatological
} diseases

\section{Katarzyna Tomaszewska ${ }^{1}$, Bożena Majchrowicz ${ }^{2}$, Magdalena Szewczyk ${ }^{3}$}

1 State Higher School of Technology and Economics in Jarosław, Institute of Health Protection

2 The East European State University in Przemyśl

${ }^{3}$ Graduate of Collegium Masoviense - College of Health Sciences 


\section{Summary}

Background: Nowadays, rheumatic diseases are increasingly recognized as chronic diseases that lead to disability, reduced quality of life and dependence on others. They are caused by pain, stiffness and reduced mobility in the joints. Early treatment and rehabilitation can improve quality of life, prolong functional abilities and independence.

Objectives: Assessment of functioning and quality of life in patients with rheumatologic diseases.

Material and methods: The study group consisted of 200 patients diagnosed with rheumatological disease. The research method was the diagnostic survey method. As a technique, the survey technique was used, and the tool for collecting data from patients was a questionnaire, consisting of two parts: a questionnaire and a standardized quality of life questionnaire SF-36.

Results: By far the greatest in the study group of patients were limitations in the performance of roles due to physical health (score at the average level of 96.8\%) and also limitations due to emotional problems (score at the average level of $72.0 \%$ ) classified as high. The severity of the study patients' limitations in physical functioning $(50.6 \%)$, severity of pain $(56.0 \%)$, assessment of general health (53.0\%) and vitality (53.5\%) were rated at medium level. The study patients' limitations in social functioning (34.8\%) and mental health $(46.2 \%)$ were relatively low.

Conclusions: The quality of life of patients with rheumatologic diseases is rated at an average level, the physical dimension was rated worse by older people and better by people with higher education.

Key words: rheumatic diseases, patient, quality of life.

\section{Background}

Rheumatic diseases are a major problem in modern health care. They are a group of diseases whose symptoms affect the locomotor system - the joints, they are chronic in nature leading, over time, to disability and invalidity and the impact of coexisting other chronic diseases on the manner and outcome of patients is significant. [1]

According to the current classification proposed in 1983 by the ARA (American College of Rheumatology), rheumatic diseases comprise over 300 entities divided into 10 groups. The current classification focuses on the symptoms and results of auxiliary and primarily laboratory tests. It is also worth mentioning that some of the diseases included in the classification have autoimmune origin and the symptoms occur in many organs simultaneously. It is estimated that rheumatoid arthritis, as the most common rheumatic disease, occurs on average in about 350 thousand Poles, which constitutes $1.5 \%$ of the population, i.e. 3 persons per 100 thousand of the total population. In Poland, the incidence rate of RA, for example, is $0.45 \%$, similar to that of the European Union. Diagnosis of the disease contributes to shortening life expectancy by up to 7 years. The disease most often occurs in people between the ages of 25 and 40, but there are cases of the disease being diagnosed in younger people as juvenile idiopathic arthritis. The peak incidence is over the age of 65 . The disease is 3 to 5 times more common in females than in males. Only $40 \%$ of patients treated for RA are employed. [2] 
Spondyloarthropathies, which include ankylosing spondylitis (AS) and psoriatic arthritis (Psoriatic arthritis), are most common after the age of 30 especially among men, and the total incidence ranges from $0.1 \%-1.4 \%$ of the population worldwide. The prevalence of AS is $23.8 \%$ per 10,000 inhabitants in Europe. More than 4,000 people are treated for AS in Poland annually. The prevalence of the disease ranges from $0.1 \%$ to $0.25 \%$. A higher proportion of patients is observed among people treated for psoriasis, with prevalence ranging from 6 to $11 \%$. [3] Another group of rheumatic diseases is osteoarthritis, which is characterized by the overlap of various conditions of different etiologies leading to various health complications. The disease is characterized by its non-inflammatory nature. The incidence of osteoarthritis increases with age. The greatest increase in the incidence occurs in people over 65 years of age with an increasing trend in people over 75 years of age. The prevalence of osteoarthritis is reported to be $80 \%$ in people over this age. [4] Most people over 55 years of age have histopathologic changes in their articular cartilage, and $80 \%$ of people can be diagnosed with degenerative changes on radiographs. On average, $10-20 \%$ of patients over 40 years of age have significantly reduced full range of motion in their joints. The disease is estimated to occur in both men and women.

When analyzing the prevalence of major rheumatic diseases, one must consider systemic lupus erythematosus, which is one of the diseases difficult to diagnose. TRU is estimated to occur in 1 in 2,000 people. The disease is more common in the black race, while in older people it more often affects the white race. Women of childbearing age account for $80 \%$ to $90 \%$ of all patients, with occasional cases among the elderly. The peak incidence is between 20 and 40 years of age. There is no accurate data on the incidence of TRU in Poland. According to the data provided by the National Health Fund in 2008, 4,000 people were treated for TRU. It is estimated that the average period from the first symptoms to the final diagnosis is 10.5 months. [2]

Rheumatic diseases and their accompanying symptoms (especially pain) significantly reduce the quality of life of patients. The chronic nature of the disease and the increasing symptoms as it progresses disturb not only the lives of patients but also their families. Many authors believe that people suffering from rheumatic diseases have significant emotional and depressive problems, which negatively affect both the physical and psychological sphere of life. [5] Patients are dominated by negative symptoms connected with pain, deformation of body posture, stiffness and restriction of joint movement, restriction of physical activity or difficulty in fulfilling social roles. Patients are accompanied by anxiety, anger, a sense of loss of control over their lives, helplessness, and limited interpersonal contacts. Symptoms of rheumatic diseases, which most often include pain and stiffness, significantly restrict mobility and the performance of daily activities, contributing to the deterioration of patients' quality of life. It is also worth mentioning that the changes affecting joints often affect internal organs, leading to disability and, in consequence, even death. The greatest chance for remission and relatively efficient life is given by early diagnosis and implementation of appropriate treatment. [6]

The application of new treatment methods gives patients a chance to return to work, perform social roles, fully enjoy social life and improve economic conditions. Considering the quality of life of patients treated for rheumatic diseases, it may be concluded that the pain and the progressive course of the disease significantly limit the proper functioning of patients. 
The support of the family, which is not only helpful in the situation of worse efficiency but also helps to accept the disease, is of great importance in this connection.

\section{Objectives}

Assessment of functioning and quality of life in patients with rheumatologic diseases.

\section{Material and methods}

The study group consisted of 200 patients treated for rheumatic diseases. The inclusion criterion for the study was the diagnosis of rheumatic disease in the patients undergoing the study. The study was conducted in a district hospital in Podkarpackie province from October 2019 to February 2020. The study population was $58.0 \%(\mathrm{~N}-116)$ female and $42.0 \%(\mathrm{~N}-84)$ male. There was one person aged 18-25 years, $4.0 \%(\mathrm{~N}-8)$ of the respondents aged 26-35 years, and $16.0 \%(\mathrm{~N}-32)$ of the respondents aged $36-45$ years. The largest group were those aged $46-55$ years at $41.0 \%(\mathrm{~N}-82)$ of people and slightly smaller, those aged $55+$ years at $38.0 \%(\mathrm{~N}-76)$ of people. Most of the respondents had basic vocational education $46.0 \%(\mathrm{~N}-$ 92) and another $30.0 \%(\mathrm{~N}-60)$ of the respondents had secondary education. Primary education was had by $5.0 \%(\mathrm{~N}-10)$ of the respondents, incomplete higher education by $6.0 \%(\mathrm{~N}-12)$ of the respondents and higher education by $13.0 \%$ (N26) of the respondents.

The study was conducted in accordance with the requirements of the Declaration of Helsinki, after obtaining approval from the CM Bioethics Committee.

\section{Statistical analysis}

In this study, the diagnostic survey method and questionnaire technique were used, and the tool used to collect data from patients was a questionnaire consisting of two parts: a questionnaire containing questions about sociodemographic data and the SF-36 quality of life questionnaire. Data collected during the study were subjected to statistical analysis, which was performed in the Statistica 13.1 package from StatSoft company, the Mann-Whitney U test and the Kruskal-Wallis Anova test were used. The level of statistical significance was taken as $\mathrm{p}<0.05$.

\section{Results}

According to Dar and Maqbool, the ultimate aim of any RA treatment should not only be to improve symptoms and functional capacity, but also to achieve a better overall quality of life for patients. In order to properly assess it in RA patients, the instrument used should be derived from the experience of the patients themselves and should be disease specific, easy to use, complete and acceptable to the respondents e.g. Short Form Health Survey-36 (SF-36). [7]

The present study aimed to present the quality of life and level of functioning of patients with rheumatological diseases. The SF-36 questionnaire was used to determine the degree of disability of the patients studied in the following spheres: physical functioning, limitations in fulfilling roles due to physical health, pain complaints, general health, vitality, social functioning, limitations in fulfilling roles due to emotional problems and mental health, as well as in physical and mental dimensions and in general.

Due to the fact that in each of the spheres and in both dimensions the respondents could obtain a different maximum number of points, in order to compare the results in relation to 
each other, they were transformed to percentage data, distributed on a scale from 0 to 100 , where a higher number of points meant a worse quality of life of the patients - a greater level of their limitations or a greater intensity of a given problem.

After the data were standardized to the values determined on a percentage scale, it became possible to assess, in relation to each other, individual spheres and dimensions more or less disturbed as a result of the rheumatological disease with which the examined patients were confronted. Always higher values on the scale meant a higher level of disability of the tested persons in a given sphere and also in a given dimension and in general.

By far the greatest in the study group of patients were limitations in role performance due to physical health (mean score 96.8\%) and limitations in role performance due to emotional problems (mean score $72.0 \%$ ) classified as high. The severity of the study patients' limitations in physical functioning $(50.6 \%)$, severity of pain $(56.0 \%)$, assessment of general health $(53.0 \%)$, and vitality $(53.5 \%)$ were rated at medium level. The study patients' limitations in social functioning $(34.8 \%)$ and mental health $(46.2 \%)$ were relatively low (Table 1)

Table 1. Percentage scores for each quality-of-life domain

\begin{tabular}{|c|c|c|c|}
\hline \multirow{2}{*}{ SF-36 Questionnaire } & \multicolumn{3}{|c|}{ Results } \\
\cline { 2 - 4 } & Raw score - mean & $\begin{array}{c}\text { Maximum number } \\
\text { of points possible } \\
\text { to obtain in a given } \\
\text { area }\end{array}$ & $\begin{array}{c}\text { Percentage of } \\
\text { points with } \\
\text { maximum }\end{array}$ \\
\hline PF & 25,3 & 50 & $50,6 \%$ \\
\hline RP & 19,3 & 20 & $96,8 \%$ \\
\hline BP & 5,0 & 9 & $56,0 \%$ \\
\hline GH & 12,7 & 24 & $53,0 \%$ \\
\hline VT & 10,7 & 20 & $53,5 \%$ \\
\hline SF & 2,8 & 8 & $34,8 \%$ \\
\hline RE & 10,8 & 15 & $72,0 \%$ \\
\hline MH & 11,6 & 25 & $46,2 \%$ \\
\hline
\end{tabular}

Legend: PF-Physical functioning; RP-Boundaries in fulfilling roles due to physical health; BP-Pain; GH-General health; VT-Vitality; SF-Social functioning; RE-Boundaries in fulfilling roles due to emotional problems;

MH-Mental health

Source: own.

The patients studied had more limitations in the physical dimension $(60.6 \%)$ than in the mental dimension (52.7\%). Their overall level of disability and limitations was, on average, $57.4 \%$ (Table 2). 
Table 2. Percentage scores for dimensions and overall quality of life.

\begin{tabular}{|c|c|c|c|}
\hline \multirow{2}{*}{ SF-36 Questionnaire } & Raw score - mean & $\begin{array}{c}\text { Maksymalna liczba } \\
\text { punktów do } \\
\text { zdobycia w danej } \\
\text { sferze }\end{array}$ & Raw score - mean \\
\cline { 2 - 4 } & 62,4 & 103 & $60,6 \%$ \\
\hline PHS & 35,8 & 68 & $52,7 \%$ \\
\hline MHS & 98,2 & 171 & $57,4 \%$ \\
\hline
\end{tabular}

Source: own.

The assessment of the quality of life of the examined patients with rheumatological diseases did not depend on their gender $(p>0.05)$. Women were slightly better than men in terms of physical functioning, and less well, in terms of mental functioning. The level of limitations of the studied patients did not depend on their place of residence $(p>0.05)$. However, it was noted that minimally greater problems in physical and mental functioning were possessed by urban residents compared to rural residents. The level of limitations of the studied patients in general $(\mathrm{p}=0.001)$ and in physical dimension $(\mathrm{p}=0.001)$ was significantly influenced by their level of education. It was shown that their quality of life was higher, and they had fewer functional and general limitations than less educated people.

The level of limitations of the studied patients was statistically significantly related to their age. This relationship was confirmed in the overall SF-36 questionnaire score $(p=0.016)$ as well as in the physical dimension $(\mathrm{p}=0.001)$. The older the subjects were, the higher their level of limitations was. Age did not affect the patients' level of functioning in the mental dimension (Table 3).

Table 3. Quality of life by age

\begin{tabular}{|c|c|c|c|c|c|c|c|c|c|c|}
\hline \multirow{3}{*}{ SF-36 } & \multicolumn{9}{|c|}{ Age } & \multirow{3}{*}{$\mathrm{p}$} \\
\hline & \multicolumn{3}{|c|}{$18-45$} & \multicolumn{3}{|c|}{$46-55$} & \multicolumn{3}{|c|}{ Above 55} & \\
\hline & $\bar{x}$ & $\mathrm{Me}$ & SD & $\overline{\bar{x}}$ & $\mathrm{Me}$ & SD & $\bar{x}$ & $\mathrm{Me}$ & SD & \\
\hline PHS & 48,3 & 48,5 & 17,8 & 61,5 & 61,2 & 13,7 & 66,4 & 66,0 & 12,4 & 0,001 \\
\hline MHS & 52,0 & 57,4 & 13,4 & 52,8 & 58,8 & 13,1 & 52,9 & 54,4 & 14,8 & 0,854 \\
\hline SF-36 & 49,8 & 49,1 & 14,0 & 58,0 & 57,9 & 10,8 & 61,0 & 61,4 & 12,1 & 0,016 \\
\hline
\end{tabular}

Source: own.

\section{Discussion}

Rheumatic diseases are chronic diseases that lead to disability and partial or total dependence on other people. Undoubtedly, chronic diseases with symptomatology characteristic of rheumatic diseases such as pain, stiffness, lack of joint movement affect the quality of life of patients, disturbing many areas of life. In practice there are many questionnaires used to assess the quality of life of patients with rheumatic diseases. In the 
author's study, the SF-36 quality of life questionnaire was used to assess the lives of patients, in this case patients treated for rheumatic diseases in several categories of functioning: physical, role limitations due to physical health; pain complaints; general health; vitality; social functioning; role limitations due to emotional problems; mental health and in two dimensions: physical and mental and overall.

The author's study showed that the greatest limitations in patients were seen in role performance due to physical health as well as emotional problems. Medium limitations in the patients in the author's study were seen in physical functioning $(50.6 \%)$, pain intensity (56.0\%), general health assessment (53.0\%), and vitality (53.5\%). Slight limitations in the patients studied were seen in social functioning (34.8\%) and mental health $(46.2 \%)$. Kowalczyk et al. in a study of patients treated for RA found that poorer quality of life was seen in the performance of activities of daily living and gainful employment, which most often correlated with pain.[8] Stawińska et al. in a study among women found that quality of life after the diagnosis was significantly worse than before the disease, most observed changes in social life and the greatest limitations were due to pain.[9] Jankowska indicates that a predictor of quality of life in patients treated for RA is physical functioning and inability to work. There is no evidence of an effect of pain on overall quality of life.[10] Kadłubowska found that men were significantly more likely to experience pain at all times of day compared to women.[11] Prajs found that older men had lower quality of life scores in terms of mental health and general health. Prajs showed that the patients studied also rated the ability to perform work less well with perceived pain. [12]

The aim of the study conducted by Wysocka-Skurska et al. was to evaluate healthrelated quality of life factors in patients with osteoarthritis and rheumatoid arthritis among 198 patients diagnosed with CAD according to American College of Rheumatology criteria and 100 patients diagnosed with RA according to American College of Rheumatology criteria. Using the SF-36 min questionnaire, it was shown that patients with osteoarthritis, despite their average older age, had higher rated quality of life than patients with RA. The overall quality of life in terms of psychological functioning in both rheumatic diseases was rated higher than in terms of physical functioning.[13] The women studied by Stawinska et al. declare that the greatest changes resulting from the disease were evident in terms of occupational performance. Most of the women were forced to give up or change their jobs.[9] Jankowska showed that people treated for RA had average scores in the psychological, somatic and environmental domains.[10]

Ambriz Murillo et al. conducted a cross-sectional study in a general hospital in Morelia, Mexico. All patients met classification criteria for rheumatic diseases. The study used different instruments min the SF-36 questionnaire. 290 subjects were evaluated (control group: 100; geriatric subjects: 30 and 160 in the other groups). SF-36 scores differed between the control group and the other groups $(\mathrm{P}=0.007)$.

The worst level of quality of life was affected by age and comorbidities. General health status was the main affected area in RZS. Pain was higher in rheumatic diseases: OA (5.2 \pm 2.4$)$ and RZS $(5.1 \pm 3)$. HAQ was higher in OA compared to RZS $(1.12 \pm 0.76$ vs. $0.82 \pm 0.82$, respectively; $\mathrm{P}=0.001)$. Forty-five percent of all subjects were depressed. [14]

In Wróbel's study, pain in patients treated for rheumatic diseases affected their interests and hobbies. However, there was no correlation between the disease and its impact 
on gainful employment, household duties, or family and social life. Wróbel emphasized that low quality of life affects mental and physical fatigue of the examined persons.[15] In Gajewski's study, the most frequent problems in patients treated for rheumatic diseases were loneliness and lack of faith in their own abilities.[16] According to Moćko, the disease affects the deterioration of economic status which, consequently, affects the deterioration of mental state.[17]

Taking into account the gender of the respondents in our study, in the assessment of quality of life there was no dependence on this issue. We can only conclude on the basis of the collected data that women functioned slightly better than men in terms of physical quality of life, on the other hand less well in terms of mental quality of life. Kowalczyk et al. also found no differences between the quality of life in men and women treated for rheumatic diseases. [8] On the other hand, the results of the study conducted by Kadłubowska prove that there was a decrease in the quality of life among the examined patients, which resulted in, among others, sleep disorders, lowered mood, motor impairment and increased fatigability. In addition, there was a decreased biopsychosocial performance among the study subjects, which affected the psychology of the study subjects. [11]

The level of limitation in the physical dimension was significantly related to the age of the patients. The older the subjects were, the higher their level of limitation was. However, age did not affect the level of patients' functioning in the mental dimension. In a study by Kowalczyk et al. the relationship between age and the domain of motor skills was demonstrated, older patients significantly lowered their quality of life, primarily in terms of occupational activity and motor skills.[8] A study by Jankowska showed that older people function worse in the psychological, social and environmental domains, thus obtaining a worse quality of life.[10] A study conducted in Finland also showed that with age, patients treated for rheumatic diseases have a worse functional capacity.[18]

Austin et al. examined the relationship between adherence to physical activity guidelines and health-related quality of life among people with arthritis among 33071 American adults. Descriptive statistics showed that $60 \%$ of adults with arthritis did not adhere to physical activity guidelines.[19] In contrast, a study by Stawinska et al. found no relationship between education and quality of life among patients; however, women living in an urban area would rate their quality of life better compared to women living in a rural area. [9] A study by Jankowska et al. showed a relationship between education and improvement in quality of life of patients treated for RA, but no relationship between place of residence and quality of life assessment.[10] Gajewski showed that people with higher education rated the quality of life significantly better and were more satisfied with it compared to those reporting lower education. In the case of the place of residence in Gajewski's study, people living in small and large cities assess the quality of life much better and thus are more satisfied with it.

According to Moćko, low education affects a worse quality of life, patients functioned worse in the physical and environmental sphere. In contrast, people with higher education rate their quality of life better.[17] Matcham et al. conducted a systematic review examining the impact of RA on quality of life as measured by the SF-36 among 22,335 patients. Meta-analyses showed that the summed mean score for the SF-36 physical component summary was 34.1 (95\% CI: 22.0-46.1) and the mental component summary was 45.6 (95\% CI: 30.3-60.8). Older adults were characterized by reduced physical fitness and physical component summary 
scores (PCS), but improved mental health and mental component summary scores (MCS). Female gender was associated with improved physical role, bodily pain, and PCS scores, but worsened mental health and MCS scores. Longer disease duration was associated with improved MCS. Patients with RA have a significantly reduced quality of life compared to other physical illnesses and compared to normative data sets from the UK and US populations.[20] According to Martinec et al. the most serious effects of rheumatoid arthritis (RA) are loss of physical function and chronic pain, which can have a major impact on various areas of a person's life.[21]

In the presented work, there are limitations related to the number surveyed respondents. However, the obtained results are important enough to continue the research undertaken on a wider group of people diagnosed with rheumatic diseases.

\section{Conclusions}

Based on the collected results of the study, the following conclusions were made: the quality of life of patients with rheumatological diseases is assessed at an average level, the examined patients have better mental than physical functioning

The quality of life of rheumatological patients was not influenced by gender or place of residence. Women functioned slightly better than men in terms of physical quality of life, but less well in terms of mental quality of life. It was shown, however, that the quality of life of the examined persons, understood in general as well as in the physical aspect, was assessed worse by elderly persons and better by persons with higher education.

Source of funding: This work was funded from the authors' own resources.

Conflicts of interest: The authors declare no conflicts of interest.

\section{References}

1. Nakajima A, Inoue E, Shimizu Y, Kobayashi A, Shidara K, Sugimoto N, Seto Y, Tanaka E, Taniguchi A, Momohara S, Yamanaka H. Presence of comorbidity affects both treatment strategies and outcomes in disease activity, physical function, and quality of life in patients with rheumatoid arthritis. Clin Rheumatol. 2015 Mar;34(3):441-9.

2. Jędryka-Góral A, Znaczenie czynników środowiskowych w etiologii tocznia rumieniowatego układowego. Reumatologia 2013; 51: 26-30;

3. Śliwczyński A, Epidemiologia zapalnych chorób stawów w Polsce. 32. Konferencja Ordynatorów i Kierowników Poradni Reumatologicznych (23-24 maja 2013), Warszawa: 2013. materiały zjazdowe.

4. Klimiuk PA, Kuryliszyn-Moskal A, Choroba zwyrodnieniowa stawów. Reumatologia 2012; 50: 162-165.

5. Kulikowski K, Psychologiczny i medyczny kontekst jakości życia osób z chorobami reumatycznymi, Reumatologia 2014;3: 200 - 206.

6. Marcol - Majewska A, Majewski G, Kotyla P, Reumatoidalne zapalenie stawów propozycje postępowania diagnostycznego, Forum Reumatologii 2017;2:88 - 92.

7. Dar MA, Maqbool M, Assessing Health - Related Quality Of Life (Qol) In Rheumatoid Arthritis., Indo Am. J. P. Sci, 2019; 06(01); 988-994 
8. Kowalczyk K, Głuszko P, Ocena jakości życia chorych na reumatoidalne zapalenie stawów za pomocą badań ankietowych, Reumatologia 2009;47: 4 - 9.

9. Stawińska T, Szulc A., Taczała J, Suwała M, Ocena jakości życia kobiet z reumatoidalnym zapaleniem stawów, Zdrowie Dobrostan 2013;2: 121 - 130.

10. Jankowska B, Uchmanowicz I, Polański J, Uchmanowicz B, Dudek K, Czynniki kliniczne I socjodemograficzne determinujące jakość życia w reumatoidalnym zapaleniu stawów, Family Medicine \& Primary Care Review 2010;12:1027 - 1034.

11. Kadłubowska M, Kózka M, Bąk E, Fraś M, Kudłacik B, Zachowania zdrowotne jako determinant strategii radzenia sobie z bólem chorych z reumatoidalnym zapaleniem stawów, Probl Hig Epidemiol 2015;96: 175 - 180.

12. Prajs K, Jakość życia chorych na reumatoidalne zapaleniem stawów w odniesieniu do sprawności fizycznej I stanu psychicznego, Annales Academiae Medicae Stetinensis Rocznik Pomorskiej Akademii Medycznej w Szczecinie 2007;2: 72 - 82.

13. Wysocka-Skurska I, Sierakowska M, Kułak W, Ocena jakości życia w przewlekłych, postępujących chorobach reumatycznych na przykładzie choroby zwyrodnieniowej stawów i reumatoidalnego zapalenia stawów Clin Interv Aging. 2016; 11:1741-1750

14. Ambriz Murillo Y, Menor Almagro R, Campos-González ID, Cardiel MH. Health related quality of life in rheumatoid arthritis, osteoarthritis, diabetes mellitus, end stage renal disease and geriatric subjects. Experience from a General Hospital in Mexico. Reumatol. Clin. 2015 Mar-Apr;11(2):68-72.

15. Wróbel A, Nawalana A, Staszkiewicz M, Majda A, Ból a funkcjonowanie chorych z reumatoidalnym zapaleniem stawów, Piel. Pol. 2017; 2:254 - 259.

16. Gajewski T, Woźnica I, Młynarska M, Ćwikła S, Strzemecka J, Bojar I, Wybrane aspekty jakości życia osób ze zmianami zwyrodnieniowymi kręgosłupa i stawów, Medycyna Ogólna i Nauki o Zdrowiu 2013; 3: 362 - 369.

17. Moćko J, Zurzycka P, Jakość życia pacjentów z reumatoidalnym zapaleniem stawów doniesienia wstępne. Piel. XXI wieku 2013; 1: 15-19

18. Sokka T, Krishnan E, Hakkinen A, Hannonen P, Functional disability in rheumatoid arthritis patients compared with a community population in Finland. Arthritis Rheum. 2003; 48: 59-63.

19. Austin S, Qu H, Shewchuk RM, Association between adherence to physical activity guidelines and health-related quality of life among individuals with physician diagnosed arthritis. Qual Life Res. 2012 Oct;21(8):1347-57.

20. Matcham F, Scott IC, Rayner L, Hotopf M, Kingsley GH, Norton S, Scott DL, Steer S. The impact of rheumatoid arthritis on quality-of-life assessed using the SF-36: a systematic review and meta-analysis. Semin Arthritis Rheum. 2014 Oct;44(2):123-30.

21. Martinec R, Pinjatela R, Balen D. Jakość życia pacjentów z reumatoidalnym zapaleniem stawów - badanie wstępne. Acta Clin Croat. 2019; 58 (1): 157-166 